\title{
Increased in vitro anticancer activity in HepG2 human hepatoma cells and in vivo hepatitis protective effect of bamboo salt
}

\author{
K. Y. Park and X. Zhao \\ Department of Food Science and Nutrition, Pusan National University, Busan 609-735, Korea
}

Bamboo salt as a functional food was originated in Korea. Bamboo salt was evaluated for the anticancer effect in human cancer cells and determined preventive effects on hepatitis in SD rats. The solar salt was filled in the internodes of young bamboo, and sealed using the natural red clay, then baked at $1000^{\circ} \mathrm{C} \sim 1500^{\circ} \mathrm{C}^{(1,2)}$ using pine as fuel. In vitro anticancer effect of the bamboo salt was evaluated in HepG2 human hepatoma cells using MTT assay (Table 1). At 1\% of salts treated HepG2 cells, showed growth inhibitory effects of bamboo salt $(9 \times, 9$ times baked) was $65 \%$, which was higher than that of bamboo salt $(1 \times)$, solar salt and purified salt $($ Hanju Corporation, Ulsan, Korea).

Table 1. Inhibitory effect of aqueous solutions from different kinds of salt products on the growth of Hep G2 cells in 3-(4,5-dimethyl-thiazol)-2, 5-diphenyl tetrazolium (MTT) assay

\begin{tabular}{lcc}
\hline & \multicolumn{2}{c}{$\mathrm{OD}_{540}(\%$ inhibited compared with control $)$} \\
\cline { 2 - 3 } Treatment & \multicolumn{2}{c}{0.5} \\
Control & \multicolumn{2}{c}{$0.581 \pm 0.004^{\mathrm{a}}$} \\
\hline Purified salt & $0.523 \pm 0.008^{\mathrm{b}}(10)$ & $0.436 \pm 0.010^{\mathrm{e}}(25)$ \\
Solar salt & $0.500 \pm 0.011^{\mathrm{c}}(14)$ & $0.413 \pm 0.007^{\mathrm{ef}}(29)$ \\
Bamboo salt $(1 \times)$ & $0.459 \pm 0.013^{\mathrm{d}}(21)$ & $0.349 \pm 0.007^{\mathrm{g}}(40)$ \\
Bamboo salt $(9 \times)$ & $0.395 \pm 0.009^{\mathrm{f}}(32)$ & $0.203 \pm 0.012^{\mathrm{h}}(65)$ \\
\hline
\end{tabular}

Table 2. Plasma AST, ALT and LDH levels

\begin{tabular}{lcrc}
\hline & \multicolumn{3}{c}{ Plasma levels (IU/L) BS: Bamboo salt } \\
\cline { 2 - 4 } & \multicolumn{1}{c}{ AST } & \multicolumn{1}{c}{ ALT } & LDH \\
\hline Normal & $169.5 \pm 12.3^{\mathrm{f}}$ & $45.7 \pm 5.6^{\mathrm{e}}$ & $1173.5 \pm 77.2^{\mathrm{f}}$ \\
Control & $1693.8 \pm 74.2^{\mathrm{a}}$ & $1438.2 \pm 82.2^{\mathrm{a}}$ & $6742.6 \pm 45.6^{\mathrm{a}}$ \\
Purified salt & $1553.1 \pm 34.5^{\mathrm{b}}$ & $998.4 \pm 65.2^{\mathrm{b}}$ & $5875.2 \pm 44.2^{\mathrm{b}}$ \\
Solar salt & $1285.3 \pm 45.2^{\mathrm{c}}$ & $804.9 \pm 34.5^{\mathrm{c}}$ & $5432.9 \pm 32.7^{\mathrm{c}}$ \\
BS $(1 \times)$ & $1077.0 \pm 25.7^{\mathrm{d}}$ & $790.2 \pm 27.6^{\mathrm{cd}}$ & $4776.4 \pm 55.2^{\mathrm{d}}$ \\
BS $(9 \times)$ & $1038.1 \pm 14.2^{\mathrm{e}}$ & $634.4 \pm 22.5^{\mathrm{d}}$ & $3877.8 \pm 37.6^{\mathrm{e}}$ \\
\hline
\end{tabular}

${ }^{\mathrm{a}-\mathrm{h}}$ Means with different letters on the bars are significantly different $(p=0.05)$ by Duncan's multiple range test $(n=3)$.

To determine the inhibitory mechanisms of apoptosis and anti-inflammatory effect of bamboo salt samples in HepG2 cells the expressions of Bax, Bcl-2 and iNOS, COX-2 genes were determined by RT-PCR. The bamboo salt $(9 \times)$ induced a stronger anticancer effect than the other salts (Fig. 1). We also evaluated whether bamboo salt exhibits hepatoprotective effects in SD-rats. Bamboo salt effectively prevented $\mathrm{CCl}_{4}$ induced hepatitis in the rats $(n=36,7$-week-old, $400 \mathrm{mg} / \mathrm{kg}$ bw of salt dissolved in water for 2 weeks). Expressions of inflammation related genes in the livers of the rats were tested. Bamboo salt $(9 \times)$ significantly decreased mRNA expressions of COX-2, iNOS, TNF- $\alpha$ and IL-1 $\beta$ (Fig 2). Bamboo salt $(9 \times$ ) showed the lowest levels of plasma AST, ALT and LDH levels (Table 2). Accordingly, bamboo salt $(9 \times)$ can be expected to contribute to prevention of hepatitis, bamboo salt $(1 \times)$ also revealed better hepatitis preventive effects than solar salt and purified salt. On the whole, bamboo salt showed much better in vitro anti-cancer activity than solar salt and purified salt in HepG2 cells and the hepatitis induced in SD rats was effectively prevented by bamboo salt.

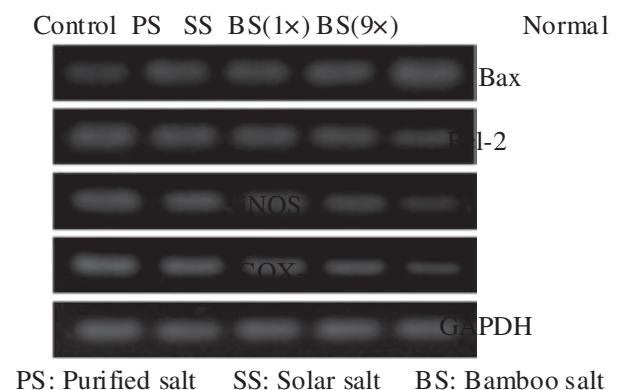

Fig. 1. Gene expression (cells).

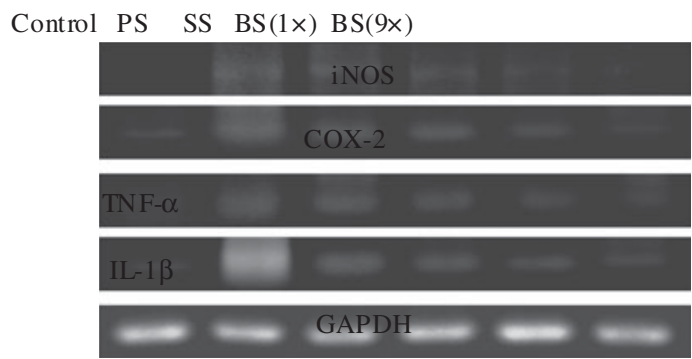

Fig. 2. Gene expression (liver).

This study was supported by the research grant (911004-02-1-HD110) from the projects for the 'Globalization of Korean Foods,' which is greatfully appreciated.

1. Shin HY, Na HJ et al. (2004) Food Ind Nutr 9, 36-45.

2. Chun H, Ying Z et al. (2000) J Agr Food Chem 48, 3170-3176. 